\title{
PC 用テンドン定着部の耐力評価に関する実験的研究 CRACKING AND ULTIMATE STRENGTH OF ANCHORAGE ZONE OF PRESTRESSING TENDONS
}

\author{
杉:田和 直*, 服部高 重**, 最上達 雄*** \\ Kazunao SUGITA, Takashige HATTORI and Tatsuo MOGAMI
}

\begin{abstract}
Loading tests of full scale specimens of the anchorage zone of prestressing tendons were carried out. Factors of the area of the cross section of members, concrete strength, and amount of lateral reinforcement (amount of spiral and hoop reinforcement) are considered to affect the cracking behavior and ultimate strength of the anchorege zone, and those factors were taken as parameters.

From the relations between each parameter and the behaviors of specimens, formulae by which cracking and ultimate strengths can be predicted are presented here. Based on a new idea of cumulative strength of concrete, and spiral and hoop reinforcement, the formulae were derived. Proposed formulae for cracking and ultimate strengths were examined by the application to the experimental data which ware published preveously, and it was confirmed that they gave.good prediction and that they were satisfactorily applicable.
\end{abstract}

Keywords : anchorage zone, prestressing tendons, full scale specimens, sectional area of members, con. crete strength, lateral reinforcement 定着部，テンドン，実大武験体；部材断面積，コンクリート強度，横補強筋

\section{1. まえがき}

日本建築学会のプレストレストコンクリート設計施工 規準・同解説では, PC 定着部の設計に際し, 支圧応力 および割裂応力に対し，それぞれ独立に許容応力度設計 を行うよう定めている。許容応力度設計の場合，許容支 圧応力は支承面積比 (支承面積 $A$ を支圧面積 $A_{0}$ で除し た值 $\left.A / A_{0}\right)$ によって変わるという考え方を取り入れて いるが, 横補強筋 (スパイラル筋, フープ筋等) の効果 を無視している。また, 割裂応力は弾性応力解析で求め; コンクリートの許容引張応力度を超過する部分に，スパ イラル筋，フープ筋等による補強を行うとしている。し かし, (1)配筋された横補強筋がその定着部の破壊耐力に 影響を及ぼすこと，(2)部材断面が大きなとき，支圧板直 下のスパイラル筋は, 通常 (支圧板と同程度) の巻径で は割裂補強としてそれほど有効でないこと，など若干の 問題が残されていると言える。なおこの点については 学会規準においても指摘されているが, 定量的な指標は 示されていない。

一方, 定着部に横補強筋を用いた支圧強度の既往の研
究は数多く報告1)-14) されているが，その多くの研 究2( -51,7),101,11)では，いずれも支承部の一辺の長さ，もし くは直径が $150 \sim 300 \mathrm{~mm}$ 程度の立方体，角柱体あるい は円柱試験体であり，試験体にはシース孔が設けられた ものは少なく，モルタル等で実施したものを含め比較的 小さな試験体が用いられている。試験体の寸法が小さく なると，ひびわれ耐力および破壊耐力が大きくなる傾向 にある(15) 17)ので，実験には実大に近い試験体を用いる ことが望ましい。

また，プレストレスト鉄筋コンクリート $(\mathrm{PRC})$ 構 造の出現により, ポストテンション工法でのコンクリー トの設計基準強度が通常の場合では $240 \mathrm{kgf} / \mathrm{cm}^{2}$ 以上, 特別な検討をした場合，またはプレストレストを補助的 に用いる場合では,これを $210 \mathrm{kgf} / \mathrm{cm}^{2}$ まで下げること ができるようになった。しかし， $300 \mathrm{kgf} / \mathrm{cm}^{2}$ 以下のコ ンクリート強度を圾った定着部耐力に関する資料が数少 な(1),3),6), 25) -18)。

以上の経緯から, 本研究では, コンクリート強度, 支 承面積, スパイラル筋量, フープ筋量をパラメータとし,

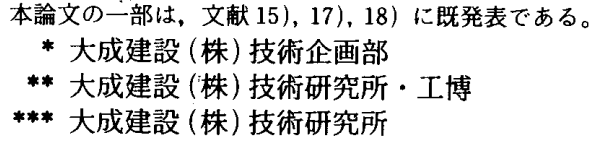

Technology Planning Department, Taisei Corporation. Technology Research Center, Taisei Corporation, Dr. Eng. Technology Research Center, Taisei Corporation: 
シース孔を設けた実大の試験体を用いて定着部耐力に関 する実験を行った。本研究の目的は，この実験結果から， 適用範囲の広い実用的に十分な精度をもつ定着部耐力推 定式を提案することである。

\section{2. 定着部の耐力実験}

\section{1 試験体}

試験体一覧表を表一1に，試験体の形状および寸法の 代表例を図一1に示す。試験体の断面は正方形で一辺 450，500，600 および $800 \mathrm{~mm}$ の 4 種とし，試験体の高 さ $H$ と支承部の一辺の長さ $B$ (以後, 部材幅という) の比 $H / B$ は 2.0 とした。これは, $H / B$ が 2.0 以上あ ればひびわれおよび破壊性状にはほとんど差が認められ ないという筆者ら ${ }^{15), 18)}$ の実験結果によるものである。

筆者らの既往の研究 ${ }^{15), 17), 18)}$ によれば, PC 定着部のひ びわれ耐力，破壊耐力に影響を及ぼす主な要因は，コン クリート強度, 支承面積比, 横補強筋量等である。本実 験のパラメータはコンクリート強度, 支承面積, スパイ ラル筋量, フープ筋量および載荷形式であり, 試験体を これらのパラメータの組合せの中から 48 体選んだ。シ リーズIの実験では，スパイラル筋量を一定（スパイラ

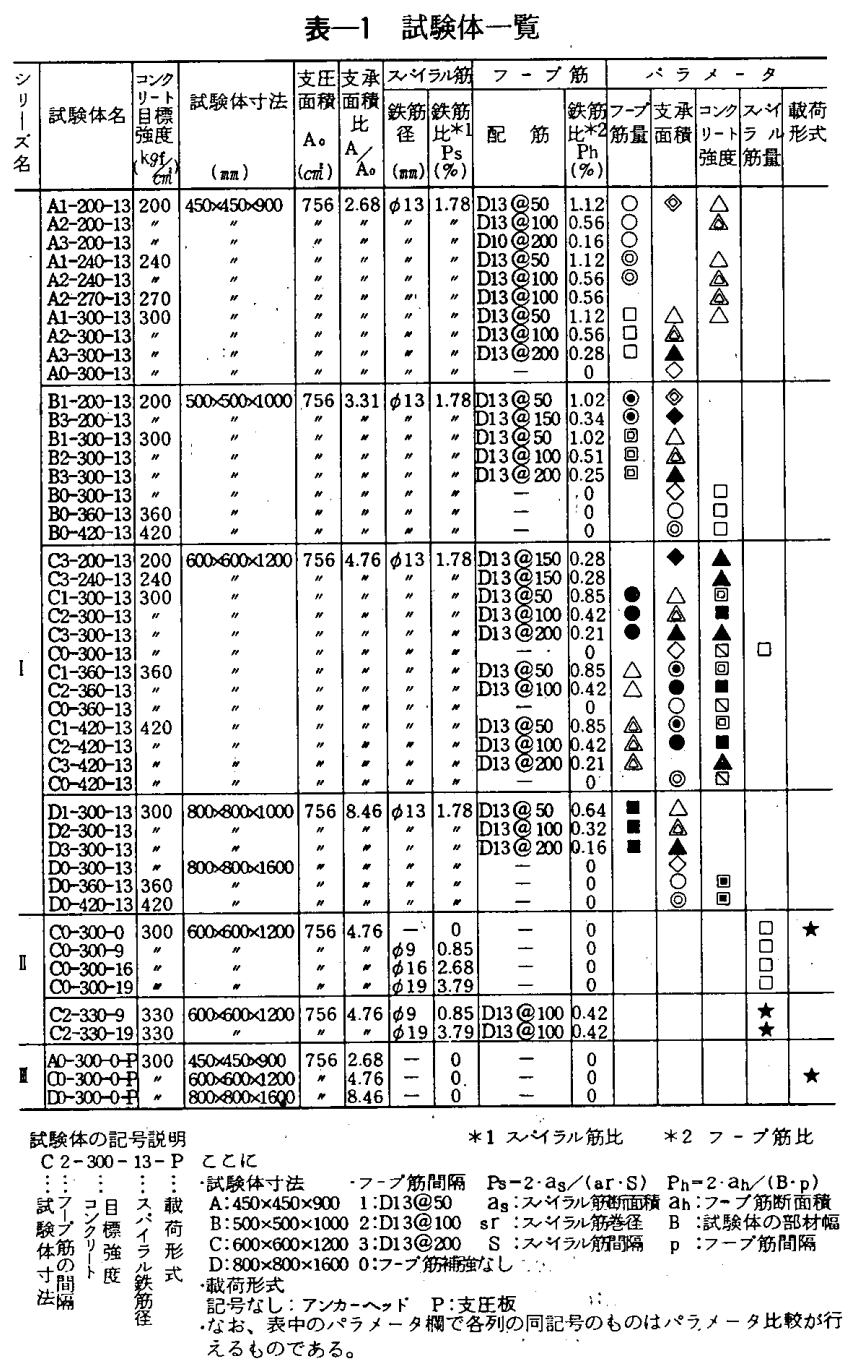

儿筋比 $1.78 \%$ 鉄筋径 $\phi 13 \mathrm{~mm}$ 巻径 $300 \mathrm{~mm}$ ピッ チ $50 \mathrm{~mm} 6$ 巻）とし, コンクリート強度, 支承面積, フープ筋量をパラメータとし，それらが矜力に及ぼす影 響を調べた。また，シリーズ【I実験では，コンクリー 卜強度, 支承面積およびフープ筋量を一定とし，スパイ ラル筋量が耐力に及ぼす影響を検討した。さらに, シリー ズIIIの実験では，載荷形式が定着部の耐力に及ぼす影響 を調べた。すなわち，シリーズ I，II では実際の定着方 法に対応させて，アンカーヘッドを介して載荷したのに 対し，シリーズ而では支圧板全面に載荷し，この影響を 検討した。なお，表中のパラメータ欄で各列の同記号の ものはパラメータ比較が行えるものである。

試験体には，現在使用されているVSL 工法の定着装 置を用いた。この定着装置は；支圧板，スパイラル筋， ジース孔およびアンカーヘッドで構成されている。支圧 板の大きさはすべて同一とし，厚さ $40 \mathrm{~mm}$ の $290 \mathrm{~mm}$ 角の鋼板を用い，支圧板面積からトランペットシース孔 （直径 $104 \mathrm{~mm}$ ）の面積を取り除いた面積を支圧面積 $A_{0}$ とした。スパイラル筋の巻径は支圧板とほぼ等しく外径 で $300 \mathrm{~mm}$ とし， スパイラル筋の高さは巻径に等しくし た。フープ筋については試験体の高さ方向全長にわたっ て配置した。

コンクリートの打込みは，試験体を水平にして行い, バイブレーターを使用し十分に締め固めを行った。試験

$$
\text { 表一2 コンクリートの試験結果 }
$$

\begin{tabular}{|c|c|c|c|c|c|c|c|}
\hline & $\begin{array}{l}\text { 县 標 } \\
\text { 强度 } \\
(\mathrm{kgf} / \mathrm{m})\end{array}$ & 姜生 & $\begin{array}{l}\text { 材 令 } \\
\text { (日) }\end{array}$ & $\mid \begin{array}{l}\text { 压樎 } \\
\text { 強度 } \\
\mathrm{kggg} / \mathrm{cm}\end{array}$ & $\begin{array}{l}\text { ヤング率 } \\
\times 10^{5} \mathrm{~kg} / \mathrm{m}\end{array}$ & $\begin{array}{l}\text { 龺 } \\
\text { 光 } \\
\text { 比 }\end{array}$ & $\begin{array}{c}\text { 引張 } \\
\text { 強度 } \\
(\mathrm{kgf} \\
\mathrm{cm})\end{array}$ \\
\hline & 200 & & 33 & 202 & 1.65 & 0.19 & 15.5 \\
\hline & & & 7 & 233 & 29 & 0.24 & 19.1 \\
\hline & 240 & & 18 & 253 & 2.15 & 0.23 & 21.5 \\
\hline & 270 & \multirow{6}{*}{$\begin{array}{l}\text { 場 } \\
\text { 封 } \\
\text { 加 } \\
\text { ん }\end{array}$} & 25 & 275 & .07 & 0.23 & 23.7 \\
\hline & 300 & & 28 & 299 & 2 & 0.23 & 27.4 \\
\hline & 360 & & 21 & 359 & 58 & 0.21 & 29.7 \\
\hline & 420 & & 69 & 416 & 05 & 021 & 33.6 \\
\hline & 300 & & 42 & 293 & 2.36 & 021 & 24.8 \\
\hline & 330 & & 8 & 324 & 2.22 & 020 & 24.0 \\
\hline
\end{tabular}

\section{表一3 鉄筋の機械的性質}

\begin{tabular}{|c|c|c|c|c|c|c|}
\hline $\begin{array}{l}\text { コンク } \\
\text { リー } \\
\text { の目標 } \\
\text { 強 度 } \\
\mathrm{kg} / \mathrm{cm}\end{array}$ & $\begin{array}{l}\text { 鉄箬の } \\
\text { 呼び名 }\end{array}$ & $\begin{array}{c}\text { 降伏 } \\
\text { 点 } \\
(\mathrm{kg} / \mathrm{f} / \mathrm{k})\end{array}$ & $\begin{array}{l}\text { 弓张 } \\
\text { 強度 } \\
(\mathrm{kgf} / \mathrm{k}) \\
(\mathrm{cm})\end{array}$ & $\begin{array}{l}\text { 伸ひ } \\
(\%)\end{array}$ & $\begin{array}{l}\text { ヤング率 } \\
\left.\times 10^{6} \mathrm{kgf} / \mathrm{m}\right)\end{array}$ & 備 \\
\hline 200 & D10 & 3840 & 5740 & 18.8 & 1.90 & フーブ筋 (SD30A) \\
\hline 240 & D1 3 & 3840 & 5760 & 18.1 & 1.92 & ( SD30A) \\
\hline \multirow[t]{2}{*}{270} & D1 6 & 3900 & 6220 & 16.6 & - & 主 筋 (SD30A) \\
\hline & $\phi 13$ & 3780 & 5530 & 28.4 & 2.20 & スソラル筋(SR24) \\
\hline$※ 1$ & D13 & 3680 & 5430 & 17.6 & 1.88 & フーブ筋 ( SD30A) \\
\hline \multirow[t]{2}{*}{300} & D1 6 & 3850 & 5710 & 24.9 & - & 主，筋 (SD30A) \\
\hline & $\phi 13$ & 3330 & 4710 & 31.3 & 2.13 & ススララル筋( SR24) \\
\hline ※2 & D1 3 & 3680 & 5430 & 17.6 & 1.88 & フーブ筋(SD30A) \\
\hline 300 & D1 6 & 3850 & 5710 & 24.9 & - & 筋 (SD30A) \\
\hline 330 & $\phi 9$ & 3730 & 5190 & 25.4 & 2.05 & スヘイラル筋(SR24) \\
\hline 360 & $\phi 13$ & 3580 & 5120 & 31.7 & 2.08 & $"$ \\
\hline \multirow[t]{2}{*}{420} & $\phi 16$ & 3360 & 4950 & 33.8 & 2.11 & " \\
\hline & $\phi 19$ & 3420 & 4980 & 30.2 & 2.07 & $"$ \\
\hline
\end{tabular}

※1 シリーズ 
体はシートがけによる気中養生であり，実験日前日に型 枠を脱型した。なお，コンクリート強度確認用の標準供 試体 $(100 \phi \times 200 \mathrm{~h})$ の養生条件は試験体之同一である。 コンクリートの試験結果を表一 2 に, 鉄笳の機械的性質 を表一 3 に示す。

\section{2 実験方法}

試験体への加力は, シリーズ I, IIでは図一2に示す ようにアンカーヘッド $(\phi 150 \times 60)$ を介して, 支圧板 $(\mathbb{P}$ $-40 \times 290 \times 290$, 材質 SS 41）を 1000 tonf 油圧式圧縮 試験機を用いて単調に載荷した。また，シリーズIIIでは 直接支圧板全面を単調に載荷した（以後，それぞれをア ンカーヘッド載荷および支圧板載荷という)。

コンクリートのひびわれ状況を観測するとともに，ス パイラル筋およびフープ筋のひずみを測定した。

\section{3 実験結果および検討}

\subsection{1 ひびわれ・破壊性状}

試験体には，補強筋がないもの（無筋），スパイラル 筋のみ配筋されたもの， スパイラル䈘とフープ筋とが配

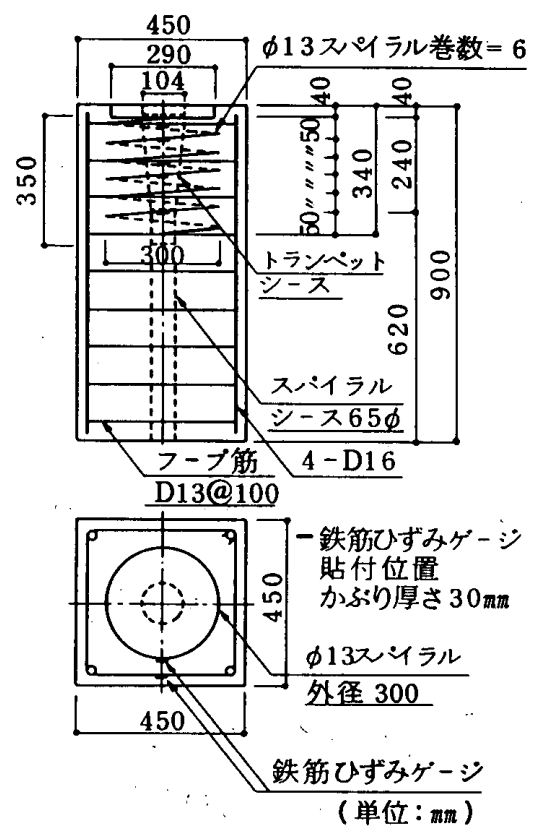

图一1＼cjkstart試験体の形状および寸法（A2-200-13）

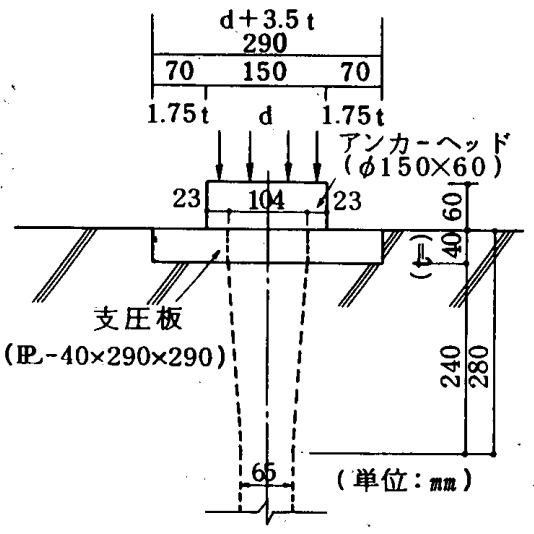

图一2 支圧板とアンカーヘッドの関係
筋されたもの 3 種類がある。いずれの試験体も，初ひび われは支圧板の下 5 10 cm のコンクリート表面に，垂 直に発生する。この縦ひびわれは，荷重の上昇とともに 下方に進展する。最終の破壊状況は，無筋またはスパイ ラル筋のみ配筋された場合, 縦ひびわれが著しく拡幅し 試験体は割裂された状態となる(写真一 1 参照)。これ に対し，スパイラル筋とフープ筋とが配筋された場合， 縦ひびわれが多数発生し全体的に破壊している（写真一 2 参照)。なお，写真一 1,2 に示す支圧板は大きく変形 しているが，これは，試験終了後内部の破壊状況を観察 するために必要以上の載加を行ったので残留変形が生じ たものである。

試験体内部の破壊状況を観察した結果を図一 3 に示 す。無筋の試験体では，支圧板直下に逆四角錐状のコー ンが形成され，このコーンが支圧板周辺のコンクリート を押し割った状態になっている(図一3(a) 参照)。なお， 支圧板載荷の試験体はアンカーヘッド載荷のものに比 べ，この逆四角錐状のコーンが大きい傾向にある。

スパイラル筋のみ配筋された試験体では，スパイラル 筋の内部に成の低いコーンが上下に対向して形成され，

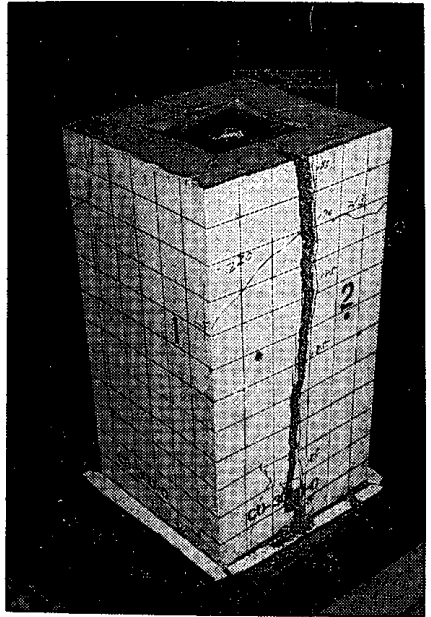

写真一1＼cjkstart無筋の場合 ( C 0-300-0 試験体)

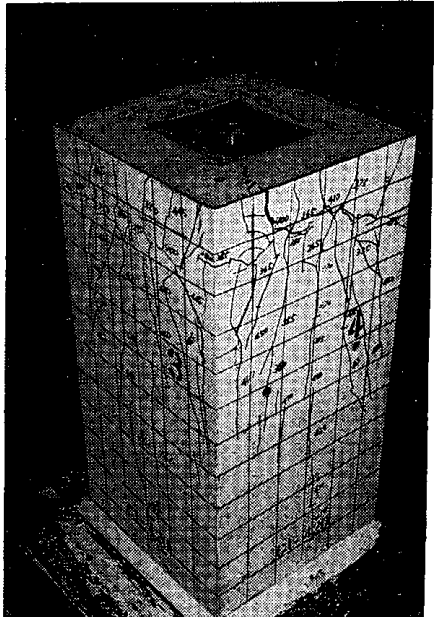

写真一2 スパイラル筋とフープ筋 とが配筋されている場合 (C1-420-13 試験体)

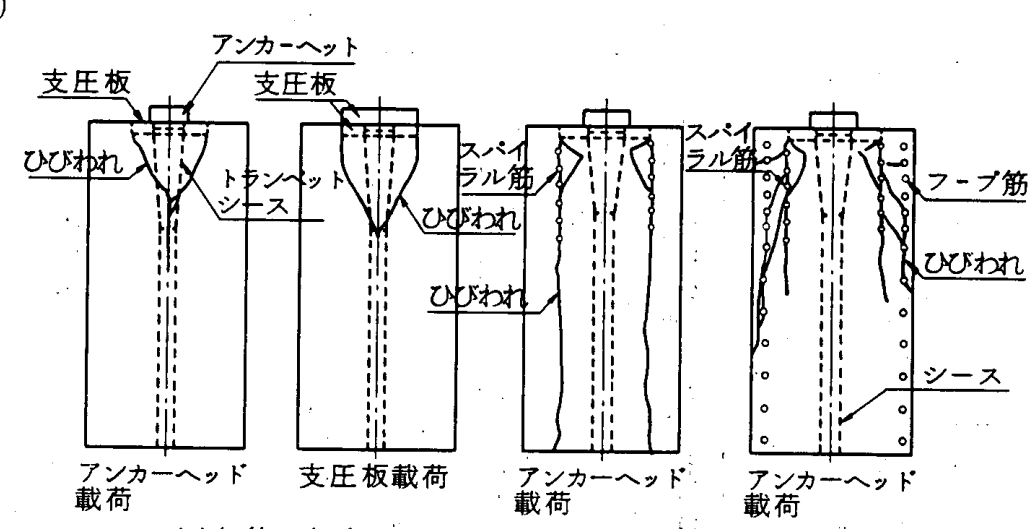

（a）無筋の場合 (b) スパイラル筋 のみの場合 (c) スパイラル筋とフープ 筋とがある場合
図一3 内部のひびわれ状況 
この部分の損傷が顕著である。さらに，スパイラル筋の 円周に沿った円筒状のひびわれが進展して, 図一3(b) に示すように周辺のコンクリートと分離した状態になっ ている。

スパイラル筋の外側にさらにフープ筋が配置される 之, 図一3(c) に示すように, スパイラル筋の外側のコ ンクリートに八の字状のひびわれが多数認められるが, スパイラル筋の内側のコンクリートの破壊状態は, 上記 のスパイラル筋のみ配筋された試験体に類似している。

以上の試験体内部の破壊状況の観察から，いずれの試 験体も支圧板の下部またはスパイラル筋の内側のコンク リートの破壊が著しく，この部分の破壊で最大耐力が決 まるものと推定された。

\section{3 .2 横補強筋のひずみ}

図一4は，シリーズIで得られたスパイラル筋とフー プ筋のひずみ測定結果の一例を示したものである。スパ イラル筋の降伏後も耐力が上昇するが, フープ筋が降伏 するとまもなく終局耐力に至る。すなわち，スパイラル 筋, フープ筋が順次降伏することにより, 拘束効果が頭 打ちになり破壊に至るものと考えられる。なお，他の試 験体においても，横補強筋はすべて最大耐力に至る前に 降伏している。

\section{3 .3 耐力に影響を及ぼす要因に関する検討}

実験結果一覧を表一 4 に示す。表中の支圧応力は荷重 を支圧面積で除した値である。

\section{表一4 実験結果一覧}

\begin{tabular}{|c|c|c|c|c|c|c|c|c|c|}
\hline \multirow[b]{2}{*}{$\frac{1}{x}$} & \multirow[b]{2}{*}{ 战騟体名 } & \multirow[b]{2}{*}{ 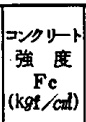 } & \multirow{2}{*}{ 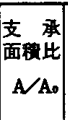 } & \multirow[b]{2}{*}{ 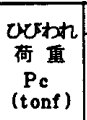 } & \multicolumn{2}{|c|}{ ひびわれ荷重時 } & \multirow[b]{2}{*}{$\begin{array}{c}\text { 最大 } \\
\text { 荷重 } \\
\mathbf{P}_{\mathbf{u}} \\
(\operatorname{tanf})\end{array}$} & \multicolumn{2}{|c|}{ 最大荷重時 } \\
\hline & & & & & \begin{tabular}{|l|} 
支任底力 \\
$\sigma_{\mathrm{c}}=\mathrm{Pc} / \mathrm{Ad}$ \\
$(\mathrm{kgf} / \mathrm{cml})$
\end{tabular} & 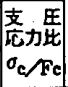 & & 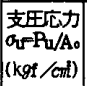 & 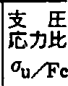 \\
\hline & \begin{tabular}{|l|}
$A 1-200-13$ \\
$A 2-200-13$ \\
$A 3-200-13$ \\
$A 1-240-13$ \\
$A 2-240-13$ \\
$A 2-270-13$ \\
$A 1-300-13$ \\
$A 2-300-13$ \\
$A 3-300-13$ \\
$A 0-300-13$
\end{tabular} & \begin{tabular}{|l|}
202 \\
202 \\
202 \\
253 \\
253 \\
275 \\
299 \\
299 \\
299 \\
299 \\
\end{tabular} & $\begin{array}{c}2.68 \\
" \\
\vdots \\
\vdots \\
\vdots\end{array}$ & $\begin{array}{l}103 \\
111 \\
100 \\
156 \\
137 \\
119 \\
141 \\
141 \\
130 \\
133 \\
\end{array}$ & $\begin{array}{l}136 \\
147 \\
132 \\
206 \\
181 \\
157 \\
186 \\
186 \\
172 \\
176 \\
\end{array}$ & \begin{tabular}{|l|}
0.67 \\
0.73 \\
0.65 \\
0.81 \\
0.72 \\
0.57 \\
0.62 \\
0.62 \\
0.67 \\
0.59 \\
\end{tabular} & \begin{tabular}{|l|}
277 \\
243 \\
193 \\
315 \\
277 \\
276 \\
342 \\
325 \\
301 \\
260 \\
\end{tabular} & $\begin{array}{l}366 \\
321 \\
255 \\
417 \\
366 \\
365 \\
452 \\
430 \\
398 \\
344 \\
\end{array}$ & $\begin{array}{l}1.81 \\
1.56 \\
1.26 \\
1.65 \\
1.45 \\
1.33 \\
1.51 \\
1.44 \\
1.33 \\
1.15 \\
\end{array}$ \\
\hline 1 & \begin{tabular}{|l|}
$\mathrm{B} 1-200-13$ \\
$\mathrm{~B} 3-200-13$ \\
$\mathrm{~B} 1-300-13$ \\
$\mathrm{~B} 2-300-13$ \\
$\mathrm{~B} 3-300-13$ \\
$\mathrm{~B} 0-300-13$ \\
$\mathrm{~B} 0-360-13$ \\
$\mathrm{~B} 0-420-13$
\end{tabular} & $\begin{array}{l}202 \\
202 \\
299 \\
299 \\
299 \\
299 \\
359 \\
416\end{array}$ & \begin{tabular}{|c|}
3.31 \\
$"$ \\
$"$ \\
$"$ \\
$"$ \\
\end{tabular} & $\begin{array}{l}143 \\
130 \\
139 \\
138 \\
138 \\
143 \\
136 \\
172\end{array}$ & $\begin{array}{l}188 \\
172 \\
184 \\
183 \\
183 \\
189 \\
180 \\
228 \\
\end{array}$ & \begin{tabular}{|l|}
0.93 \\
0.85 \\
0.62 \\
0.61 \\
0.62 \\
0.63 \\
0.50 \\
0.55 \\
\end{tabular} & $\begin{array}{l}289 \\
244 \\
326 \\
327 \\
301 \\
268 \\
289 \\
312 \\
\end{array}$ & $\begin{array}{l}382 \\
323 \\
479 \\
432 \\
398 \\
354 \\
382 \\
413 \\
\end{array}$ & $\begin{array}{l}1.89 \\
1.60 \\
1.60 \\
1.44 \\
1.33 \\
1.18 \\
1.06 \\
0.99 \\
\end{array}$ \\
\hline & 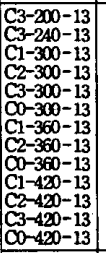 & $\begin{array}{l}202 \\
233 \\
299 \\
299 \\
299 \\
299 \\
359 \\
359 \\
359 \\
416 \\
416 \\
416 \\
416 \\
\end{array}$ & \begin{tabular}{|c|}
4.76 \\
$" \prime$ \\
$" \prime$ \\
$" \prime$ \\
$" \prime$ \\
$\because " \prime$ \\
$" \prime$ \\
$" \prime$ \\
$"$ \\
\end{tabular} & $\begin{array}{l}167 \\
189 \\
192 \\
194 \\
171 \\
158 \\
253 \\
235 \\
213 \\
288 \\
261 \\
251 \\
235 \\
\end{array}$ & $\begin{array}{l}221 \\
250 \\
254 \\
257 \\
226 \\
209 \\
335 \\
311 \\
282 \\
381 \\
345 \\
332 \\
311 \\
\end{array}$ & \begin{tabular}{|l|}
1.09 \\
1.07 \\
0.86 \\
0.86 \\
0.76 \\
0.70 \\
0.93 \\
0.87 \\
0.79 \\
0.92 \\
0.83 \\
0.80 \\
0.75 \\
\end{tabular} & $\begin{array}{l}265 \\
306 \\
390 \\
357 \\
329 \\
283 \\
437 \\
396 \\
302 \\
467 \\
433 \\
400 \\
343 . \\
\end{array}$ & $\begin{array}{l}350 \\
405 \\
516 \\
472 \\
435 \\
374 \\
578 \\
524 \\
399 \\
618 \\
573 \\
529 \\
452 \\
\end{array}$ & $\begin{array}{l}1.73 \\
1.744 \\
1.73 \\
1.58 \\
1.45 \\
1.25 \\
1.61 \\
1.46 \\
1.11 \\
1.49 \\
1.38 \\
1.27 \\
1.09 \\
\end{array}$ \\
\hline & \begin{tabular}{|l|}
$1-300-13$ \\
$D 2-300-13$ \\
$D 3-300-13$ \\
$D 0-300-13$ \\
$D 0-360-13$ \\
$D 0-420-13$ \\
\end{tabular} & \begin{tabular}{|l|}
299 \\
299 \\
299 \\
299 \\
359 \\
416 \\
\end{tabular} & $\begin{array}{c}8.46 \\
": \\
": \\
": \\
\end{array}$ & $\begin{array}{l}250 \\
250 \\
255 \\
248 \\
274 \\
295 \\
\end{array}$ & $\begin{array}{l}331 \\
331 \\
337 \\
328 \\
362 \\
390 \\
\end{array}$ & \begin{tabular}{|lll}
1.1 & 1 \\
1.1 & 1 \\
1.1 & 3 \\
1.1 & 0 \\
1.0 & 1 \\
0.9 & 4 \\
\end{tabular} & $\begin{array}{l}433 \\
401 \\
364 \\
320 \\
387 \\
415 \\
\end{array}$ & $\begin{array}{l}573 \\
530 \\
481 \\
423 \\
512 \\
549 \\
\end{array}$ & $\begin{array}{l}1.92 \\
1.77 \\
1.61 \\
1.41 \\
1.43 \\
1.32 \\
\end{array}$ \\
\hline 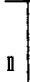 & \begin{tabular}{|l|}
$C 0-300-0$ \\
$C 0-300-9$ \\
$c 0-300-16$ \\
$C 0-300-19$
\end{tabular} & $\begin{array}{l}293 \\
2993 \\
293 \\
293\end{array}$ & $\begin{array}{c}4.76 \\
": \\
"\end{array}$ & $\begin{array}{l}189 \\
209 \\
205 \\
211\end{array}$ & $\begin{array}{l}250 \\
276 \\
27.1 \\
279\end{array}$ & \begin{tabular}{|l|}
0.85 \\
0.94 \\
0.92 \\
0.95 \\
\end{tabular} & $\begin{array}{l}229 \\
255 \\
310 \\
330 \\
\end{array}$ & $\begin{array}{l}303 \\
337 \\
410 \\
437 \\
\end{array}$ & $\begin{array}{l}1.03 \\
1.15 \\
1.40 \\
1.49 \\
\end{array}$ \\
\hline & \begin{tabular}{|c|}
$C 2-330-9$ \\
$C 2-330-19$
\end{tabular} & $\begin{array}{l}324 \\
324 \\
\end{array}$ & 4.76 & $\begin{array}{l}215 \\
213\end{array}$ & $\begin{array}{l}304 \\
308\end{array}$ & $\begin{array}{l}0.94 \\
0.95\end{array}$ & $\begin{array}{l}328 \\
431\end{array}$ & $\begin{array}{l}434 \\
570\end{array}$ & $\begin{array}{l}1.34 \\
1.76\end{array}$ \\
\hline & $\mid$\begin{tabular}{|c|}
$A 0-300-0 P$ \\
$C 0-300-0=$ \\
$D 0-300-0 P$
\end{tabular} & $\begin{array}{l}293 \\
293 \\
293\end{array}$ & \begin{tabular}{|l|}
2.68 \\
4.76 \\
8.46
\end{tabular} & $\begin{array}{l}223 \\
287 \\
450\end{array}$ & $\begin{array}{l}295 \\
380 \\
595\end{array}$ & \begin{tabular}{|l|}
0.97 \\
1.30 \\
1.95
\end{tabular} & $\begin{array}{l}314 \\
350 \\
469\end{array}$ & $\begin{array}{l}415 \\
463 \\
620\end{array}$ & $\begin{array}{l}1.37 \\
1.58 \\
2.04 \\
\end{array}$ \\
\hline
\end{tabular}

ひひわれ荷重は 4 面に生じた何重の平均である。
以下に，コンクリート強度, 支承面積比, スパイラル 筋量およびフープ筋量の各要因が支圧応力に及ぼす影響 について検討する。

\section{(1) コンクリート強度}

図一5は，スパイラル筋量を一定 $\left(P_{s}=1.78 \%\right)$ と した試験体で，コンクリート強度と支圧応力との関係を 示したものである。ひびわれ荷重および最大荷重時の支 环応力 $\left(\sigma_{c}\right.$ および $\left.\sigma_{u}\right)$ はコンクリート強度の上昇に伴 い直線的に増大するが, 支圧応力の増大の割合は支承面 積比によって異なる。すなわち，支承面積比が大きくな ると直線の勾配が大きくなる傾向にあるので, 支承面積 比によってコンクリート強度の評価を変える必要があ る。

\section{（2）支承面積比}

上記のコンクリート強度の影響を取り除くため, 支圧 応力をコンクリート強度で除した支圧応力比を縦軸に,

支承面積比を横軸に取って，両対数軸上に図示すると図

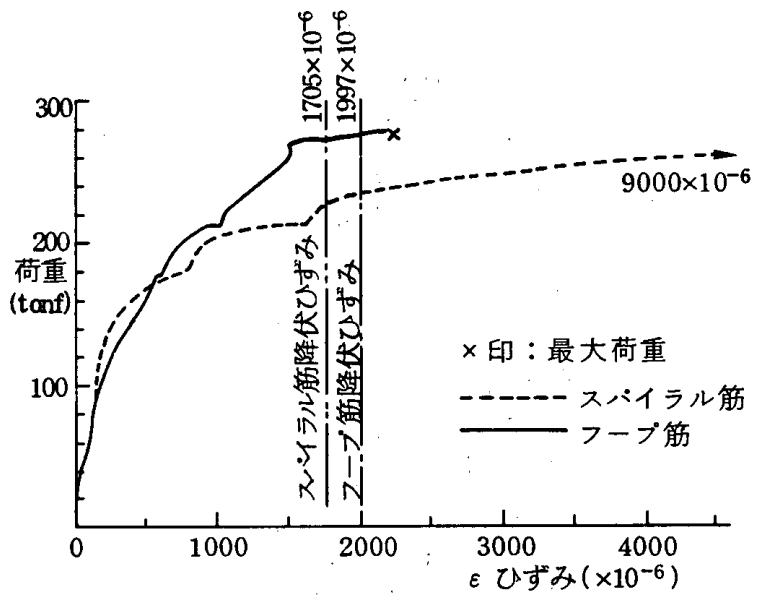

図一4 スパイラル筋ひずみとフープ筋ひずみの比較 (A 1-200-13)

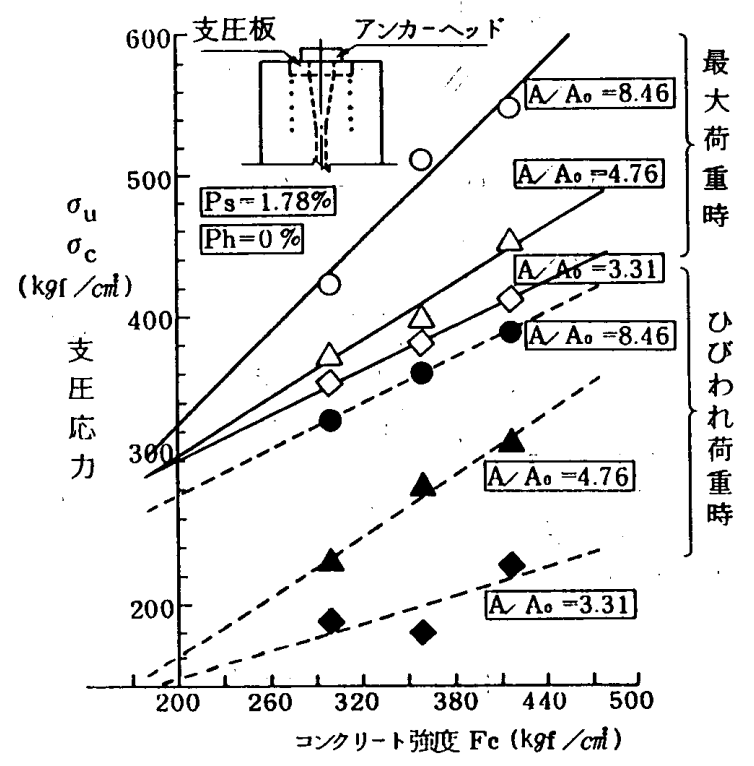

図一5 コンクリート強度と支圧応力の関係 
一6が得られる。なお，多くの研究者らも年,19) 27)このよ うに両対数軸上で支圧応力比と支承面積比の関係で整理 している。図一6では, 同一のスパイラル筋量 $\left(P_{s}=\right.$ $1.78 \%$ ）の試験体について, コンクリート強度とフー プ筋間隔との組合せが同じものを 1 つの記号で示した。 この図より，支承面積比が大きくなれば $\sigma_{c} / F_{c}$ および $\sigma_{u} / F_{c}$ は直線的に大きくなると言える。この直線の勾配 は, 他のパラメータ (コンクリート強度, フープ筋間隔) が変化してもほぼ一定とみなしてよいことが分かる。

\section{（3） スパイラル筋量}

$P_{s}{ }_{s} \sigma_{y}\left(P_{s}\right.$ ：スパイラル筋比, ${ }_{s} \sigma_{y}$ : スパイラル筋の 降伏点）亡支圧応力との関係を図一7に示す。この図よ り，スパイラル筋量が大きくなるほど支圧応力が直線的 に上昇することが分かるが，ひびわれ補強にはスパイラ ル筋の効果がそれほよ゙ないと言える。また，スパイラル 筋量によるこれらの直線の勾配は, 他のパラメータ（コ ンクリート強度, フープ筋量) が変化してもほぼ一定と みなしてよいことが分かる。

\section{（4）フープ筋量}

図一8はスパイラル筋量を一定 $\left(P_{s}=1.78 \%\right)$ とし た試験体で, $P_{h} \cdot{ }_{h} \sigma_{y}\left(P_{h}:\right.$ フープ筋比, ${ }_{h} \sigma_{y}:$ フープ筋 の降伏点）と支圧応力との関係を示したものである。こ の図より,フープ筋量が大きくなれば, 支圧応力が直線 的に上昇することが分かる。しかし，スパイラル筋の場 合之同様に，ひびわれ補強に対してフープ筋の効果はわ ずかしかないと言える。また，フープ筋量によるこれら の直線の勾配は, 他のパラメータ（コンクリート強度, 支承面積比 $A / A_{0}$ ） が変化してもほぼ一定とみなしてよ いことが分かる。すなわち，スパイラル筋の場合と同様 に, フープ筋の補強効果は他の要因とは独立に評価でき ると言える。

\subsection{4 耐力機構および実験式の構成}

上記のひびわれ・破壊性状および各 要因の検討結果を要約すれば，次のよ うになる。

(1) 支圧板より外側のコンクリートは 割裂破壊を生じているが，最終的な破 壊原因は支圧板直下のコンクリートの コーン状の滑り破壊によるものと考え られる。

(2) 支圧耐力（ひびわれ耐力および破 壊耐力）はコンクリート強度に比例す る。この比例定数は, 支承面積比の増 大につれ，大きくなる。

(3) 支圧応力比は支承面積比の増大に つれて大きくなるが，比例関係にはな い（両対数軸図上では直線関係であ る)。
(4) 支圧耐力は横補強筋量 $\left(P_{s} \cdot{ }_{s} \sigma_{y}\right.$ または $\left.P_{h} \cdot{ }_{h} \sigma_{y}\right)$ に 比例して増大し，この比例定数は他の要因の影響を受け ない。

なお，横補強筋はいずれも最大荷重に至るまでに降伏

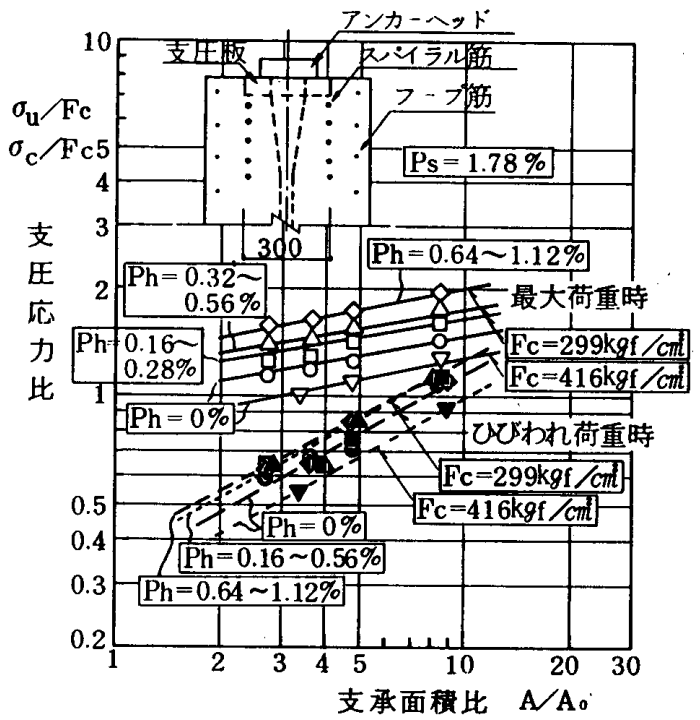

图一6 支承面積比亡支圧応力比の関係

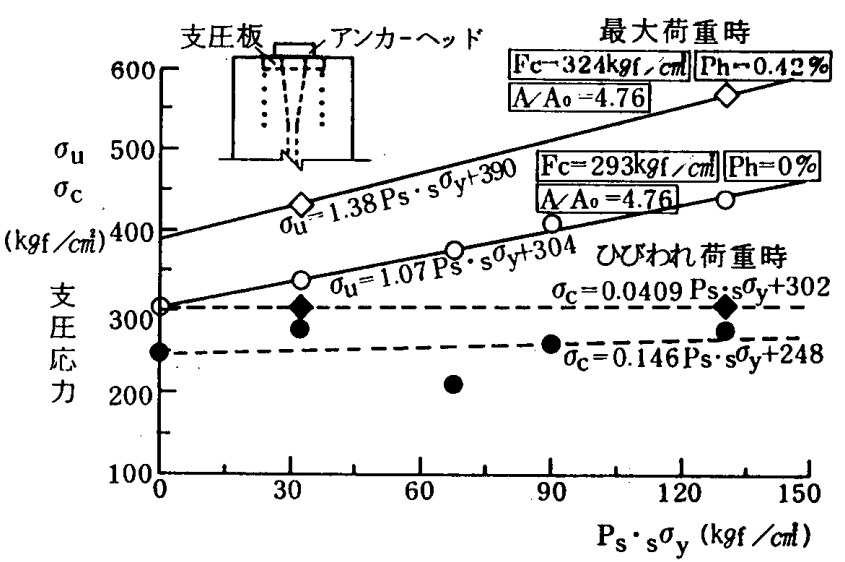

图一7 $P_{s} \cdot{ }_{s} \sigma_{y}$ と支圧忘力の関係

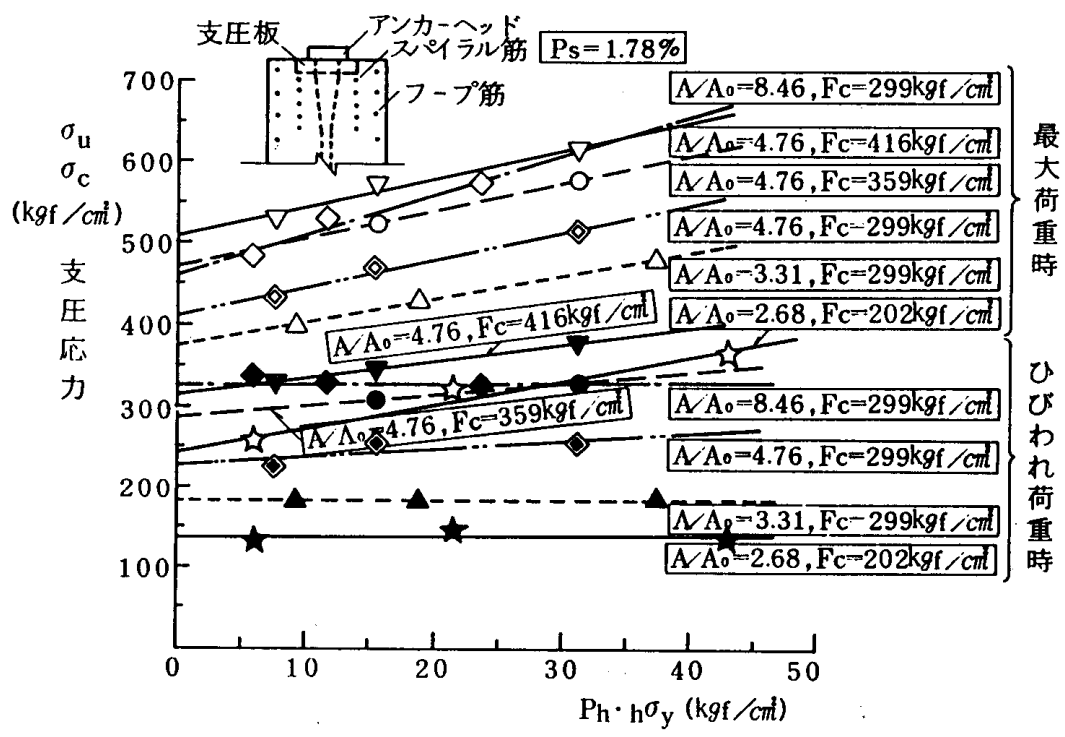

図一8 $\quad P_{h} \cdot{ }_{h} \sigma_{y}$ と支圧応力の関倸 


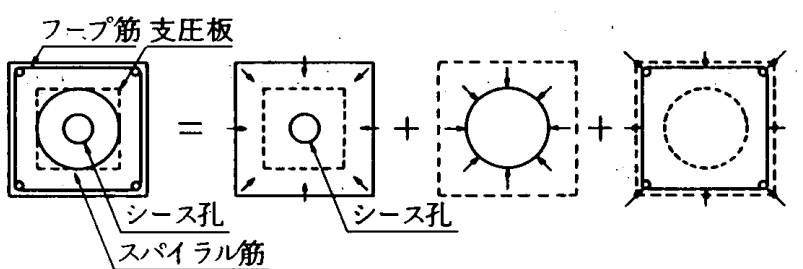

$\begin{array}{ccc}\text { PC定着部 } & \text { コンクリート項 スパイラル筋に フーブ筋によ } \\ \text { の耐力 } & \text { よる耐力增加項 る耐力增加項 }\end{array}$

图一9 支圧板より外側の横方向の拘束

している。

以上の要約から，耐力機構を図一9のようにモデル化 して考える。すなわち，全面圧縮強度 $\left(F_{c}\right)$ に対する支 圧耐力の増大を, 図示のように支圧板より外側のコンク リートの拘束効果 $\left(A / A_{0}\right)$ を考虑したコンクリート項に, スパイラル筋およびフープ筋の 2 種類の横方向の拘束効 果による耐力増加項が，それぞれに独立に累加されるも のと考える。

上記の拘束効果によって支圧板下部のコンクリートが 3 軸圧縮応力状態になるため, 支圧耐力が全面圧縮強度 （1 軸圧縮応力状態）よりも増大することを容易に説明 できる。また，この耐力増大分が 1 軸圧縮耐力に独立に 累加されるという考え方も一般的である。すなわち，横 方向から等水圧 $\left(\sigma_{0}\right)$ を受ける場合のコンクリートの軸方 向圧縮強度を $\sigma_{u}=F_{c}+k_{0} \sigma_{0}$ ( $k_{0}$ : 定数) で表現した

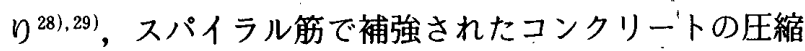
強度を $\sigma_{u}=F_{c}+k P_{s} \cdot{ }_{s} \sigma_{y}\left(k:\right.$ 定数)で表現するように ${ }^{30)}$, 横方向の拘束効果を全面圧縮強度に累加する手法は広く 行われている。図一9に示す耐力機構もこのような考え 方を採用しているが， 3 種類の耐力を独立に累加したの は，支生板より外側のコンクリートが割裂破壊し，横補 強筋がすべて降伏して，それぞれの拘束効果が破壊酎力 に十分に寄与していると考えたからである。

支圧耐力を求める実験式の構成は, 図一9 から次式の ように表現される。

$$
\sigma_{u}=f_{1}\left(F_{c}, A / A_{0}\right)+f_{2}\left(P_{s} \cdot{ }_{s} \sigma_{y}\right)+f_{3}\left(P_{h} \cdot{ }_{h} \sigma_{y}\right)
$$

\section{ここに, $f_{1}, f_{2}, f_{3}$ : 関数}

$\sigma_{u}:$ 最大荷重時の支王応力 $\left(\mathrm{kgf} / \mathrm{cm}^{2}\right)$

$A / A_{0}$ : 支承面積比
$A$ : 支承面積 $\left(\mathrm{cm}^{2}\right)$
$A_{0}$ : 支圧面積 $\left(\mathrm{cm}^{2}\right)$
$F_{c}$ : コンクリートの圧縮強度 $\left(\mathrm{kg} \mathrm{f} / \mathrm{cm}^{2}\right)$

\subsection{5 無補強コンクリートの支圧応力比}

定着部の耐力は，（1）式に示すように，無補強コン クリートの耐力にスパイラル筋とフープ筋の補強効果を 累加することにようて与えられると仮定した。（1）式 の右辺第二項および第三項はそれぞれスパイラル筋と フープ筋の耐力上昇効果であり, 図一 7,8 に定量的に把

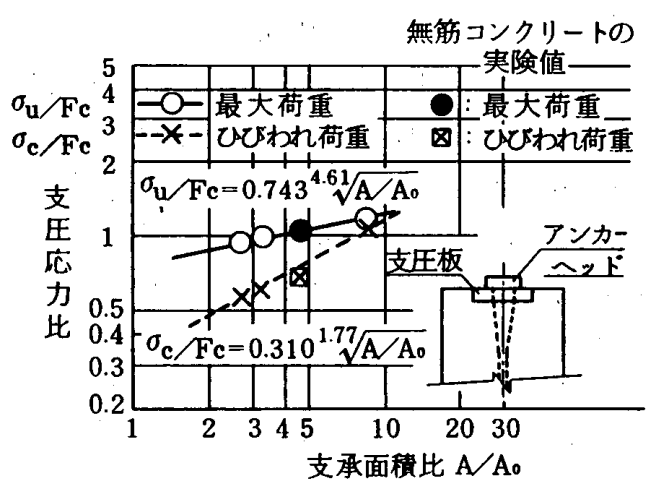

图一10 支圧応力比と $A / A_{0}$ の関係

握できている。しかし，図一6は, 横補強筋の効果も含 めた耐力であり，第一項の無補強コンクリートの支圧応 力比と支承面積比の関係は求められていない。そこで, 図一7 から得られるスパイラル筋量による耐力上昇分を 図一 6 より差し引き, 無補強コンクリートの支圧応力比 と支承面積比の関係を求め，これを示したものが図一10 である。すなわち, 図一7の支圧応力と $P_{s}{ }_{s} \sigma_{y}$ 関係の 両辺を $F_{c}$ で除し, スパイラル筋によって増加する耐力 $\sigma_{c} / F_{\mathrm{c}}=0.15 P_{s} \cdot{ }_{s} \sigma_{y} / F_{c}$ および $\sigma_{u} / F_{c}=1.1 P_{s}{ }_{s} \sigma_{y} / F_{c}$ を 図-6 の $F_{c}=299 \mathrm{~kg} \mathrm{f} / \mathrm{cm}^{2}, P_{s}=1.78 \%, P_{h}=0 \%$ の 直線から差し引き, 無補強コンクリートの耐力を導いた ものである。

上述の操作によって, 無補強コンクリートのひびわれ 応力, 最大応力を推定したものを $\times$ 印および○印で示し, これから求められるそれぞれの耐力式も図中に示した。 この累加の考え方を検証するために行った無補強コンク リート試験体 (1 体) の実験結果を区印および○印で記 入した。区，○印は耐力式（点線および実線）のほぼ線 上にある。

\section{3. 耐力評価式の提案}

耐力に寄与するコンクリート強度と支承面積比，スパ イラル筋量およびフープ筋量のそれぞれの効果が定量的 に把握できたので，実験式の誘導が可能である。(1) 式の $f_{1}, f_{2}, f_{3}$ の関数の形は, 図一 $7,8,10$ より, 以下 のようになる。

$$
\sigma_{u}=\alpha\left(A / A_{0}\right)^{\beta} \cdot F_{c}+\gamma\left(P_{s} \cdot{ }_{s} \sigma_{y}\right)+\delta\left(P_{h} \cdot{ }_{h} \sigma_{y}\right)
$$

なお， $\alpha, \beta, \gamma, \delta$ は実験定数である。

3.1 定数の決定

定数は図一 $7,8,10$ のそれぞれの回㷌式の直線の傾き から求められ，図一7ではデー夕数の多い方を，図一8 では平均的な值を採用した。この結果，それぞれ次式の ように実験式（以後, 耐力評価式という）が得られた。

(1) ひびわれ耐力

$\sigma_{c}=0.31 \cdot \sqrt[1.8]{A / A_{0}} \cdot F_{c}+0.15 P_{s} \cdot{ }_{s} \sigma_{y}+0.71 P_{h} \cdot{ }_{h} \dot{\sigma}_{y}$ 
(2) 最大耐力

$\sigma_{u}=0.74 \cdot \sqrt[4.6]{A / A_{0}} \cdot F_{c}+1.1 P_{s} \cdot{ }_{s} \sigma_{y}+3.2 P_{h}{ }^{\cdot} \sigma_{y}$

ただし, $180 \leqq F_{c} \leqq 450 \quad\left(\mathrm{kgf} / \mathrm{cm}^{2}\right), \quad 2 \leqq A / A_{0} \leqq 10$, $0<P_{s} \leqq 4.0(\%), 0 \leqq P_{h} \leqq 1.2(\%), F_{c}$ ( リンダー $100 \phi \times 200 \mathrm{~h}$ の圧縮強度）

ここに,

$\sigma_{c}=P_{c} / A_{0}:$ ひびわれ荷重時の支圧応力 $\left(\mathrm{kgf} / \mathrm{cm}^{2}\right)$

$P_{c}:$ ひびわれ荷重 $(\mathrm{kgf})$

$\sigma_{u}=P_{u} / A_{0}$ : 最大荷重時の支圧応力 $\left(\mathrm{kg} \mathrm{f} / \mathrm{cm}^{2}\right)$

$P_{u}$ : 最大荷重 $(\mathrm{kgf})$

$\left.P_{s}=2 \cdot a_{s} /{ }_{s} r \cdot S\right):$ スパイラル䈘比

$a_{s}$ : スパイラル筋の断面積 $\left(\mathrm{cm}^{2}\right)$

${ }_{s} \sigma_{y}:$ スパイラル筋の降伏点 $\left(\mathrm{kgf} / \mathrm{cm}^{2}\right)$

${ }_{s} r$ : スパイラル筋の巻径 $(\mathrm{cm})$

$S:$ スパイラル筋の間隔 $(\mathrm{cm})$

$P_{h}=2 \cdot a_{h} /(B \cdot p):$ フープ筇比

$a_{h}:$ フープ筋の断面積 $\left(\mathrm{cm}^{2}\right)$

${ }_{h} \sigma_{y}:$ フープ筋の降伏点 $\left(\mathrm{kgf} / \mathrm{cm}^{2}\right)$

$B$ : 部材幅（支承部の一辺の長さ） $(\mathrm{cm})$

$p:$ フープ筋の間隔 $(\mathrm{cm})$

なお, 耐力評価式の $F_{c}, A / A_{0}, P_{s}$ および $P_{h}$ の適用 範囲は，本実験の範囲からそれほど外抻することなく， 無理のない範囲に定めたものである。

\section{2 耐力評価式の精度}

シリーズ I, II の実験データのひびわれ荷重および最 大荷重とそれぞれの耐力評価式による計算值との比較を 図一11に示す。実験值は計算值に対しおおむね土10\% の範囲内におさまっており，耐力評価式は実験值を精度 良く近似していると言える。

\section{4. 本研究の実験值が小さいことに対する検討}

既往の研究21,201,211,24) で得られた実験式と本研究の耐力 評価式の第一項（コンクリート項）とを比較して表一5 に示す。表一 5 にみられるように本研究の耐力評価式は, 他の実験式に比べて，小さめの評価となっている。これ は載荷方法による差異, 試験体の大きさの影響等による ものと考えられ，この点を以下に考察する。

\section{1 載荷方法による差異}

図一12 は無筋コンクリートの支圧応力比と支承面積 比の関係について，アンカーヘッド載荷と支圧板載荷と を比較したものである。この図において，アンカーへッ ド載荷したものの支圧応力比は支圧板載荷したものに比 ベかなり小さくなっており $\left(A / A_{0}=4.76\right.$ でアンカー ヘッド載荷は支圧板載荷したものの約 $65 \%$ である), 載荷方法の差異が顕著に現れている。この差異は，支纴 板にシース穴があるため，アンカーヘッド載荷では支圧 板の曲げ剛性が小さくなった影響が現れたものと考えら

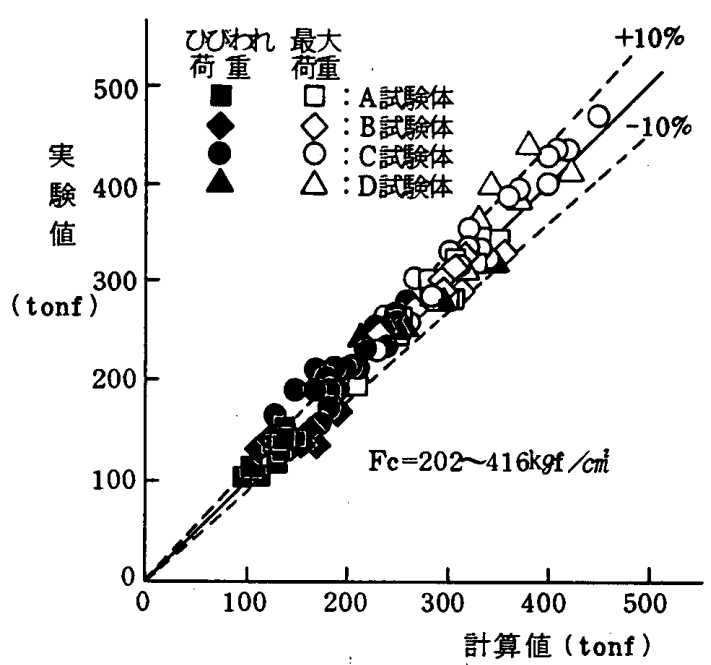

図一11 実験値と計算値の比較

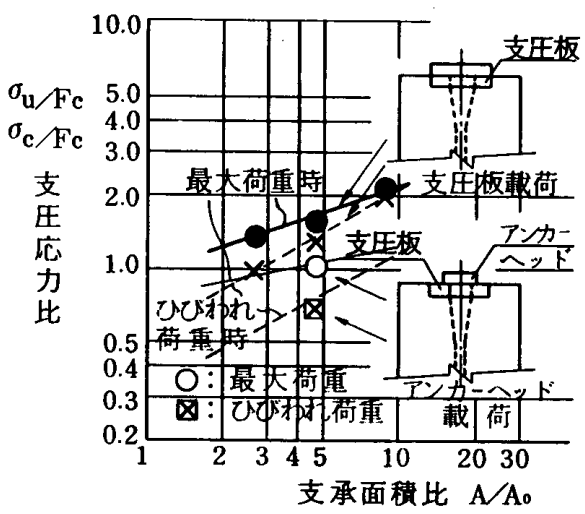

図一12 $A / A_{0}$ と支圧応力比の関係

表一5 既往の研究との比較

\begin{tabular}{|c|c|c|c|c|}
\hline \multirow[b]{2}{*}{ 研究者 } & \multicolumn{2}{|c|}{ 実 験 時 の } & \multirow[b]{2}{*}{ 提 案 式 } & \multirow{2}{*}{$\begin{array}{l}\mathrm{A}_{\mathrm{A}}=4.76 の \\
\text { ときの } \sigma_{\mathrm{u}} \text { の値 }\end{array}$} \\
\hline & 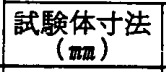 & $\begin{array}{c}\mathrm{Fc} \\
\left(\mathrm{kgf} / \mathrm{cm}^{\mathrm{m}}\right)\end{array}$ & & \\
\hline 鉿木 $ら^{2)}$ & $203 \times 002 \times 500$ & $305 \sim 364$ & $\sigma_{\mathrm{u}}=0.9\left(\mathrm{~A} / \mathrm{A}_{0}\right)^{0.6} \cdot \mathrm{Fc}$ & $2.30 \mathrm{Fc}$ \\
\hline 一未 20$)$ & $300 \times 300 \times 360$ & $148 \sim 163$ & $\sigma_{\mathrm{u}}=1.39 \sqrt[13]{\mathrm{A} / \mathrm{A}_{0}} \cdot \mathrm{FC}_{\mathrm{C}}$ & $3.44 \mathrm{Fc}$ \\
\hline 伊東 ${ }^{21)}$ & $250 \times 250 \times 250$ & 342 & $\sigma_{\mathrm{u}}=\sqrt[224]{\mathrm{A} / \mathrm{A}_{0}} \cdot \mathrm{Fc}$ & $2.02 \mathrm{Fc}$ \\
\hline 六車 $5^{24)}$ & $200 \times 200 \times 200$ & 400 & $\sigma_{\mathrm{U}}=0.84 \sqrt[2.13]{\mathrm{A} / \mathrm{A}_{0}} \cdot \mathrm{Fc}$ & $1.66 \mathrm{Fc}$ \\
\hline 本研究 & \begin{tabular}{|l|}
$450 \times 450 \times 000$ \\
$800 \times 800 \times 1600$
\end{tabular} & & $\sigma_{\mathrm{u}}=0.74 \sqrt[4.6]{\mathrm{A} / \mathrm{A}_{0}} \cdot \mathrm{Fc}$ & $1.04 \mathrm{Fc}$ \\
\hline
\end{tabular}

れる。なお，支压板載荷の場合， $A / A_{0}=1.0$ すなおち, 全面載荷では $\sigma_{u} / F_{c} \fallingdotseq 1.0$ となっていて，この影響は現 れていない。表一 5 に示した既往の研究では, 支圧板全 面に載荷を行っているので, 本研究で得られた耐力評価 式に比べて，高めの実験式を与えているものと考えられ る。

\section{2 試験体の大きさの影響}

図-13 は試験体の寸法効果を調べるため, 筆者らが 別に行った実験（試験体寸法, 支王板寸法, シース孔径, スパイラル筋巻径, フープ筋加工寸法, アンカーヘッド 径等がほぼ相似のものを用い, コンクリート強度, 支承 面積比, スパイラル筋量およびフープ筋間隔を一定とし 


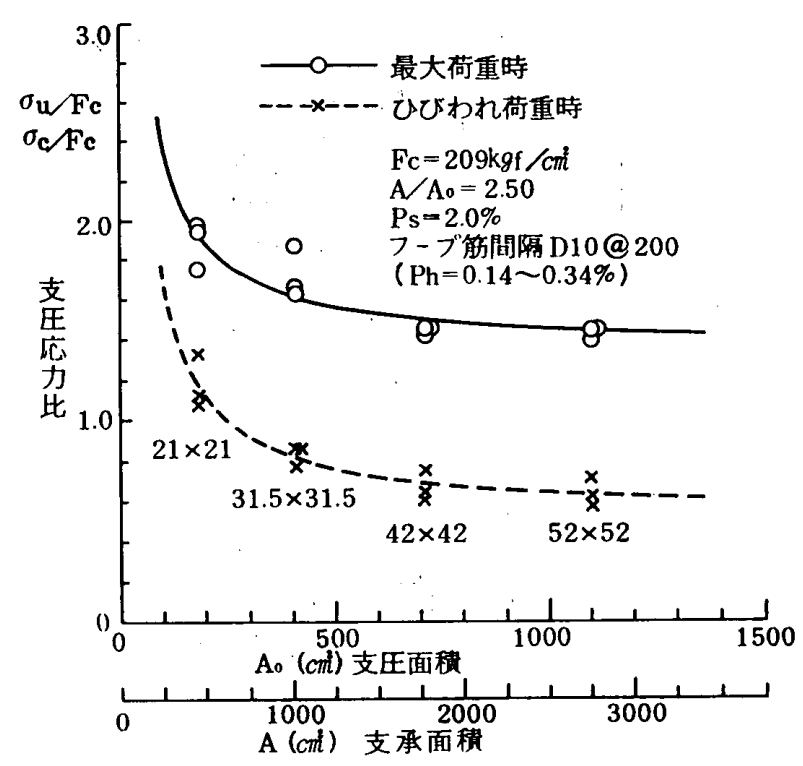

図一13，支圧応力比と支承面積 $A$ の関係

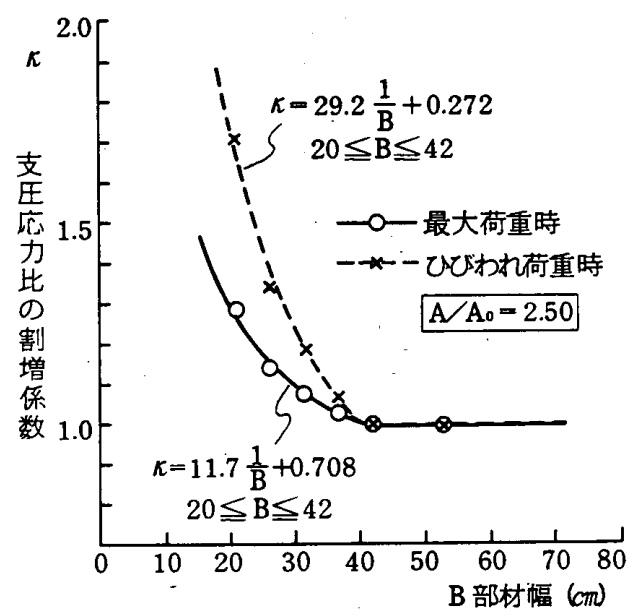

図一14 部材幅と支圧応力比の割增係数の関係

た ${ }^{177}$ から, 支圧応力比と支承面積との関係を回帰分析 により求めたものである。この実験の範囲では, 支承面 積が大きくなるほどひびわれ荷重および最大荷重時の支 圧応力比は小さくなるが, 支承面積が約 $1770 \mathrm{~cm}^{2}$ (42 $\times 42 \mathrm{~cm}$ 角, 図中の数值は部材幅を示す) 以上になると, 支圧応力比はほぼ一定となる。本研究の実験は実構造物 に用いられる大容量テンドンの定着具を使用し, 支承面 積が約 2025 6 $400 \mathrm{~cm}^{2}$ と大きいので, 耐力評価式を小 さい部材に適用する場合には，補正が必要となる。

図一14 は，部材幅によって耐力を補正する時に使用 するもので, 図一13 の部材幅 $42 \mathrm{~cm}$ の部材を基準とし て,これより小さい部材の割増係数を求めたものである。

\section{5. 耐力評価式の検討}

5.1 筆者らが過去に得た実験データ

文献 16）の実験值と耐力評価式による計算値との比 較を図一15 a に示す。この実験は，系統的な実験になっ ていないので, 実験デー夕を本研究の耐力評価式の誘導

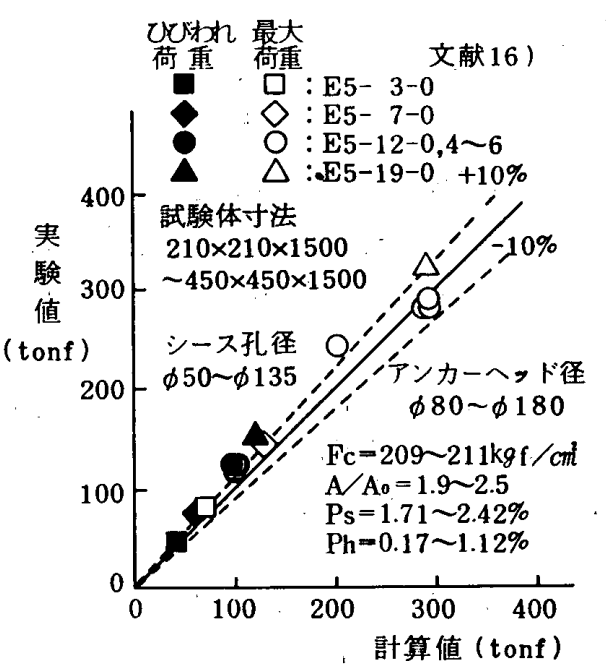

（注）試験体記号は文献16）を 参照のとと

图一15 a 実験値と計算値の比較

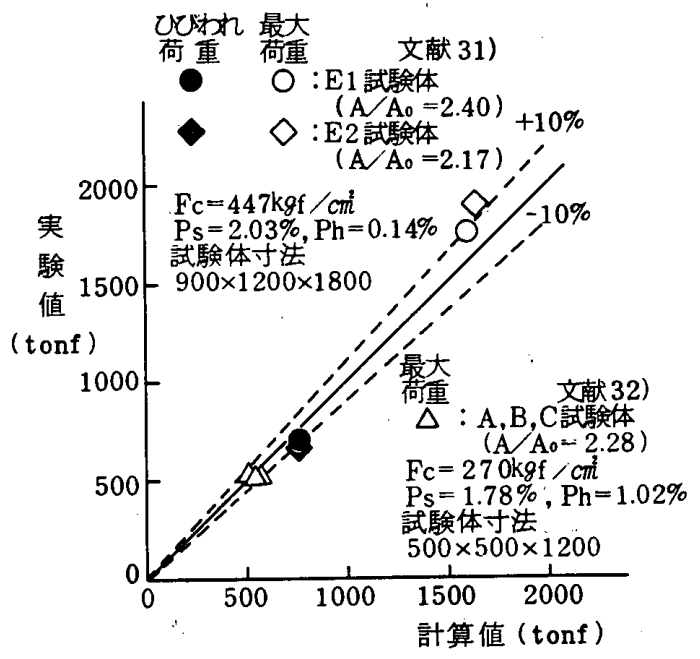

（注）試験体記号はそれぞれ 文献31）,32）を参照のてと

図一15b 実験値と計算值の比較

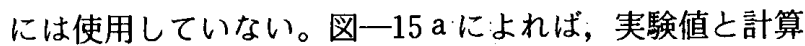
値とはおおむねよく一致している。なお，実験条件はコ ンクリート強度 $F_{c}$ が $209 \sim 211 \mathrm{kgf} / \mathrm{cm}^{2}$, 支承面積比 $A / A_{0}$ が1.9 2.5， スパイラル筋量 $P_{s}$ が $1.71 \sim 2.42$ $\%$ ，フープ筋量 $P_{h}$ が $0.17 \sim 1.12 \%$ である。

5.2 既往の文献 ${ }^{311}$.32) による検討

文献 31），文献 32）の実験值と耐力評価式による計算 值との比較を図一 $15 \mathrm{~b}$ に示す。文献 31)，32）は試験体 数がそれぞれ 2 体および 3 体と数少ないが，それぞれ断 面の極めて大きい場合への適用と他の工法（ディビダー クストランド工法）に対して適用が可能かどうかを調べ た。実験值と計算值とはおおむね一致しており，本耐力 評価式は大断面の部材とディビダークストランド工法に 対しても適用が可能であると言える。

\section{6. まとめ}

実際の構造物に即した形状および寸法の試験体を用い 
た実験から，PC 定着部の横補強筋 (スパイラル筋, フー プ筋）を考慮したひびわれ耐力および破壊耐力を推定す る精度の高い実験式を提案した。この実験式は PC 定 着部の支圧耐力をコンクリートの耐力とスパイラル筋お よびフープ筋の耐力との累加とした新しい考え方による ものである。筆者らが過去に得た実験デー夕および既往 の文献による実験データをこの実験式に当てはめた結 果, 良く一致し, 耐力評価式として十分適用できること が確認された。

なお，定着装置は支厈板，スパイラル筋，シース孔お よびアンカーヘッドで構成され，本実験に用いたものと 同様の形状，寸法，同質の材料等の定着具で構成される 他の工法に対しても本耐力評価式は適用が可能であると 考えられる。

\section{謝 辞}

本研究に際し, 御助言を頂いた日本大学 工博 矢代秀 雄教授, 大成建設 (株) 技術研究所工博 吉崎征二氏に 深く感謝致します。

\section{参考文献}

1）斉藤雄三：低強度コンクリート用 PC ケーブル定着装置, プレストレストコンクリート,Vol. 26, No. 1, pp. 96〜102, Jan. 1984 年

2）鈴木計夫，中塚 佶：円形補強筋をもつ PC 鋼材定着部 の強度および破壊機構に関する研究，日本建筑学会論文 報告集，第 315 号，pp. 17 28，昭和 57 年 5 月

3）鈴木計夫, 中塚 佶：円形補強筋をもつ $\mathrm{PC}$ 鋼材定着部 の強度および破壊機構に関する研究，日本建築学会論文 報告集，第 341 号，pp. 19２6，昭和 59 年 7 月

4）鈴木計夫，中塚 佶，畠木 斉：PC 鋼材定着部の終局 強度設計法に関する基礎的研究，七メント技術年報, pp. 495 498, 昭和 58 年

5) S. K. Niyogi : Bearing Strength of Reinforced Concrete Brocks, Journal of the Structural Division, ASCE, Vol. 101, No. ST5, pp. 1125 1137, May 1975

6）山田邦光, 千葉折雄, 金成貞男 : PC 緊張端の研究, プ レストレストコンクリート, Vol.11, No.1, pp. 50〜 59, March, 1969 年

7）藤井 学, 鍋野幹夫：局部支圧を受ける補強コンクリー トのひびわれおよび破壊安全率について，セメント技術 年報, pp. $444 \sim 449$, 昭和 48 年

8）萩谷英二，後藤幸正，野口俊介：PC 鋼棒の定着部の補 強に関する研究, 土木学会東北支部年次学術講演会, pp. $312 \sim 313$, 昭和 56 年

9）三浦 尚，萩谷英二：薄肉断面における $\mathrm{PC}$ 鋼棒定着部 の補強方法に関する研究，セメント技術年報，pp. 479 482 , 昭和 56 年

10）藤井学, 荒木 毅, 塩屋俊幸: 局部支圧を受ける補強 コンクリートの変形と破壊, セメント技術年報, pp. 356 $\sim 359$, 昭和 50 年

11）六車 熙, 岡本 伸：局部荷重を受けるコンクリートの 支圧強度に関する実験的研究，セメント技術年報, pp. 368 372, 昭和 39 年

12）石橋忠良：アンカープレートの配置間隔に関する実験的 研究, プレストレストコンクリート, Vol.23, No. 3, pp. 12 22, May 1981 年

13）松本英信, 安原 明, 狩野誠一郎：PC アンカー部のひ びわれ荷重, 土木学会年次学術講演会, pp. 405 406, 昭和 50 年

14）日本建築学会構造標準委員会：鉄筋コンクリート終局強

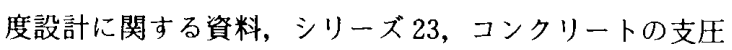
強度, 日本建築学会建築雑誌, Vol.96, No. 1180, pp. 71 ～78, 1981 年 6 月号

15）杉田和直, 最上達雄, ほか 2 名：低強度コンクリートを 用いるPS 定着部の耐力性状に関する実験研究, プレス トレストコンクリート, Vol.28, No. 3, pp. 39〜54, May 1986

16）杉田和直, 最上達雄, 阿部 訟, 渡辺武久： $300 \mathrm{~kg} \mathrm{f} / \mathrm{cm}^{2}$ 未満のコンクリートに用いる定着部の耐力実験，プレス トレストコンクリート技術協会, 第 25 回研究発表会講演 概要, pp. 23 26, 1985 年 11 月

17）杉田和直，最上達雄：横補強筋を有するPS 定着部の耐 力評価に関する研究，プレストレストコンクリート技術 協会, 第 26 回研究発表会講演概要, pp. 1 4, 1986 年 10 月

18）杉田和直, 最上達雄, 江崎哲郎, 阿部 陸: PS 定着部 の耐力性状に関する実験研究, プレストレストコンクリー 卜技術協会, 第 25 回研究発表会講演概要, pp. 19 22, 1985 年 11 月

19）藤井 学：軽量コンクリートの支玕強度, 材料, 第 18 巻, 第 185 号, pp. 74 81, 昭和 44 年 2 月

20）一木保夫：コンクリート支承面が局部的に荷重を受ける 場合のコンクリートの許容支圧応力度実験式並びにその 適用限界に就いて，内務省士木試験報告，No. $60, p p .89$ $\sim 105,1941$ 年 3 月

21）伊東茂富：コンクリートの支圧強度に関する実験的研究, セメントコンクリート，No.123，pp.9〜15，1957 年 5 月

22) W. Shelson : Bearing Capacity of Concrete, Journal of the American Concrete Institute, pp. 405 414, November 1957

23) H.P. Spieth : Das Verhaltan von Beton unter hoher ortlicher Pressung, Benton and Stahlbetonbau Vol.56, No. 11, pp. 257 263, 1961

24）六車 熙, 岡本 伸：局部荷重を受けるコンクリートの 支圧強度に関する研究, プレストレストコンクリート， Vol. 9, No. 5, pp. 22 29, October 1963

25）小阪義夫, 谷川恭雄：コンクリートの支圧強度と供試体 寸法之の関係，セメント技術年報，pp. 493 497，昭和 42 年

26）佐治泰次：モルタルおよびコンクリートの部分圧縮強度 について, コンクリート・ジャーナル, Vol.4, No.1, pp. 16 25, Jan. 1966

27) S. K. Niyogi: Concrete Bearing Strength-Support, Mix, Size Effect, Journal of the Structural Division, ASCE, Vol. 100, No. ST8, pp. 1685 1702, Aug. 1974

28) Blume J.A., Newmark N. M. and Corning L. H. : Design of Multistory Reinforced Concrete Buildings for 
Earthquake Motions（金多，潔訳：超高層鉄筋コンク リート建築の耐震設計, 日本セメント協会, pp. 99, 昭 和 40 年)

29）森田司郎, 小阪義夫：鉄筋コンクリート構造, 丸善 (株), p. 73

30）安田正雪, 桝田佳寛, 橋爪 進, 山下時夫, 高羽 登： 高強度コンクリートの横拘束時の力学特性（その 2 横 拘束時の力学特性), 日本建築学会大会学術講演梗概集, pp. 25 26, 1989 年 10 月
31）井垣 力, 近藤 茂, 只野直典：PCCV 用テンドンの摩 擦損失等測定試験, プレストレストコンクリート, Vol. 23, No. 1, pp. 116 125, Jan. 1981

32）石原重孝, 竹田哲夫, 夏目忠彦, 岩㴊 明, 合津信貞, 赤崎重雄：500 $\mathrm{t}$ テンドンシステムの開発一ディビダーク ストランド工法一プレストレストコンクリート, Vol.26, No. 2, pp. 50 58, Mar. 1984

(1990 年 6 月 10 日原稿受理, 1991 年 1 月 28 日採用决定) 